\title{
Produksi Rennet Mucor pusillus yang Ditumbuhkan pada Limbah Padat Tapioka (Onggok)
}

\author{
The Production of Rennet Enzyme Extracted from Mucor pusillus Cultured in “onggok" \\ Medium
}

\begin{abstract}
Abdul Choliq
Bidang Mikrobiologi, Pusat Penelitian Biologi, LIPI, Jl. Raya Jakarta-Bogor Km 46 Cibinong 16911 E-mail: choliq_lipi@yahoo.com
\end{abstract}

\begin{abstract}
The production of rennet enzyme extracted from Mucor pusillus in "onggok" medium the effect of incubation peptone and ammonium nitrate to enzyme production, and the effect of $\mathrm{pH}$ and temperature to the activities of rennet were found. The statistical method used is Completed Randomized Design with 3 replicates for each treatment, with the rennet activity in $\mathrm{RU} / \mathrm{ml}$ enzyme extract. The rennet production was conducted in erlenmeyer $(100 \mathrm{ml})$ that contain $17.5 \mathrm{~g}$ "dry onggok" and $50 \mathrm{ml}$ solution of suspension used. The effect of incubation time was detected in three incubation times $(4,7$, and 10 day), while effect of peptone and ammonium nitrate to the production of the rennet enzyme was detected in 4 concentrations $(0,1,2$, and $3 \%)$ for 7 days of incubation times. The effect of $\mathrm{pH}$ to the activity of rennet from the treatment of adding peptone $1 \%$ with 7 days incubation time was detected in $5 \mathbf{p H}$ variation $(5,5.5,6,6.5$ and 7$)$ while the effect of temperature were detected in 5 variations $\left(30,35,40,45\right.$, and $\left.50^{\circ} \mathrm{C}\right)$. The research results showed that the time of incubation, the addition of peptone and ammonium nitrate affected significantly to enzyme production of rennet Mucor pusillus in “onggok” medium. The highest production of the rennet enzyme products was in the addition of peptone $1 \%(12.53$ $\mathrm{RU} / \mathrm{ml}$ ) with 7 days incubation time. On the treatment of temperature and $\mathrm{pH}$, the optimum activity of rennet Mucor pusillus was in $\mathrm{pH} 5.5(40.03 \mathrm{RU} / \mathrm{ml})$ and the activity of rennet Mucor pusillus increased up to temperature of $50^{\circ} \mathrm{C}$.
\end{abstract}

Key words: rennet, Mucor pusillus

Diterima: 29 Januari 2008, disetujui: 15 Agustus 2008

\section{Pendahuluan}

Rennet adalah enzim kasar yang berasal dari hewan, tanaman atau mikrobia, yang mempunyai kemampuan untuk menggumpalkan susu. Susu dalam bentuk cair cepat mengalami kerusakan pada waktu penyimpanan dikarenakan adanya aktivitas bakteri psikotrof (Khusniati et al., 1997; Khusniati, 2001). Oleh karena itu peran rennet sebagai penggumpal susu dapat menghasilkan produk susu dalam bentuk gumpalan sebagai keju yang tahan lama selama penyimpanan. Secara tradisional, enzim yang digunakan sebagai penggumpal susu adalah rennin atau chymosin. Enzim tersebut diekstrak dari abomasum anak sapi yang belum makan apaapa kecuali air susu induknya.

Pemanfaatan rennet sapi untuk pembuatan keju sudah berlangsung lama. Sejak ratusan tahun yang lalu manusia memanfaatkan enzim lambung anak sapi untuk pembuat keju. Akibatnya telah terjadin pembunuhan sapi muda dalam jumlah yang besar dan mengancam populasi ternak sapi di beberapa negara Eropa pada tahun 70-an (Cheesman, 1981).

Mengingat berbagai masalah yang berkaitan dengan rennet sapi (calf rennet), baik 
menyangkut kontinuitas bahan baku maupun aspek kehalalan, saat ini para produsen keju sudah mulai mengembangkan dan menggunakan mikrobia rennet (rennet yang berasal dari mikrobia). Mikrobia rennet dihasilkan dari proses fermentasi mikrobia tertentu yang bisa menghasilkan enzim rennet. Dengan proses mikrobia ini produktivitas dapat ditingkatkan tanpa harus mengalami kendala bahan baku. Medium yang digunakan untuk memproduksi rennet jenis ini adalah bahanbahan yang berasal dari susu, seperti susu skim, whey powder dan sumber nutrisi lain seperti gula (sukrosa) dan yeast extract (ekstrak khamir). Namun demikian rennet sapi memiliki karakteristik khas yang tidak bisa ditiru oleh rennet mikrobia sehingga jenis keju tertentu dengan kualitas tertentu terpaksa masih harus menggunakan rennet sapi.

Mucor meihei, Mucor pusillus, dan Edonthia parasitica adalah mikrobia-mikrobia penghasil rennet dalam jumlah yang banyak, mudah dalam penyiapan media pertumbuhan dan mudah dalam mengektraksi enzimnya. Mikrobia-mikrobia tersebut memiliki aktivitas koagulasi tinggi, tetapi aktivitas proteolitiknya rendah. Tingkat koagulasi dalam proses pembuatan keju sangat tergantung jenis rennet yang digunakan, misalnya aktivitas koagulasi rennet Mucor pusillus lebih tinggi dibandingkan aktivitas koagulasi rennet anak sapi (Stenberg, 1976; Cheesman, 1981). Bila digunakan untuk membuat keju, rennet tersebut dapat menghasilkan keju yang baik, tanpa rasa pahit, flavornya disukai dan rendemen keju tinggi.

Mucor pusillus dapat memproduksi protease pada berbagai medium, namun untuk memproduksi rennet lebih cocok ditumbuhkan pada medium padat dan menghasilkan enzim beberapa kali lipat lebih banyak (Sastraatmadja et al., 2000). Dalam tulisan ini dibahas hasil penelitian mengenai produksi enzim rennet dari Mucor pusillus dalam medium limbah tapioka dengan penambahan pepton dan ammonium nitrat, dan karakterisasinya pada berbagai $\mathrm{pH}$ dan suhu.

\section{Metode Penelitian}

Kapang Mucor pusillus yang digunakan dalam penelitian ini diperoleh dari koleksi Bidang Mikrobiologi, Pusat Penelitian Biologi, LIPI, Cibinong.

\section{Penyiapan inokulan}

Suspensi biakan kapang Mucor pusillus ditumbuhkan dalam medium tauge agar $\left(37^{\circ} \mathrm{C}\right)$ selama tiga hari. Setelah itu ke dalam biakan ditambahkan air suling steril, dikocok untuk mendapatkan larutan suspensi sampai kepekatan optik 0,5 diukur dengan spektrofotometer pada panjang gelombang 620 $\mathrm{nm}$.

\section{Produksi enzim rennet}

Metode yang digunakan dalam produksi enzim rennet adalah modifikasi metode Arima (1976). Produksi enzim rennet dilakukan dalam Erlenmeyer (100 ml) yang berisi 17,5 g limbah padat tapioka dalam $50 \mathrm{ml}$ air suling atau larutan yang akan digunakan. Sebelum dicampur, onggok dan larutannya disterilisasi pada temperatur $121^{\circ} \mathrm{C}$ selama 15 menit secara terpisah. Pengamatan pengaruh waktu inkubasi terhadap rennet yang dihasilkan dilakukan dalam 3 variasi waktu inkubasi (4, 7, 10 hari). Pengaruh penambahan pepton dan amonium nitrat dilakukan dengan 4 macam konsentrasi $(0,1,2,3 \%)$ pada waktu inkubasi 7 hari. Setelah didapatkan hasil tertinggi aktivitas rennet terhadap pengaruh penambahan pepton dan ammonium nitrat, dilakukan pengamatan terhadap $\mathrm{pH}(5 ; 5,5 ; 6 ; 6,5 ; 7)$ dan suhu $(30,35$, 40, 45, dan $50^{\circ} \mathrm{C}$ ).

Rancangan Penelitian dan Analisis data yang digunakan adalah rancangan acak lengkap dengan uji Scheffe dengan 3 kali ulangan untuk setiap perlakuan dengan parameter aktivitas rennet $(\mathrm{RU} / \mathrm{ml})$.

\section{Ekstraksi enzim rennet}

Sebanyak 15 g medium yang telah ditumbuhi kapang dipindahkan ke dalam Erlenmeyer (300 ml), ditambahkan $150 \mathrm{ml}$ air suling dan $3 \mathrm{ml}$ toluene. Ekstraksi dilakukan dengan mesin pengocok selama 60 menit, selanjutnya disaring dan filtratnya ditampung serta disimpan pada temperatur $0^{\circ} \mathrm{C}$. 


\section{Penentuan aktivitas rennet}

Penentuan aktivitas rennet menggunakan metode Babel dan Somkuti (1968). Sebanyak 20 g susu skim bubuk dilarutkan dalam $100 \mathrm{ml}$ air suling, diaduk sampai homogen. Sepuluh ml larutan susu skim 20\% tersebut dimasukkan ke dalam tabung reaksi, diatur suhunya $30^{\circ} \mathrm{C}$, ditambahkan $1 \mathrm{ml}$ ekstrak rennet, dan diamati waktu koagulasinya yang ditandai dengan timbulnya bercak/ gumpalan-gumpalan kecil pada dinding tabung reaksi.

\section{Perhitungan}

Aktivitas rennet $=\frac{10 \times \mathrm{P}}{Q-R} R U / \mathrm{ml}$

$\mathrm{P}=$ Jumlah susu yang digunakan (ml)

$\mathrm{Q}=$ Jumlah ekstraksi (enzim yang digunakan (ml))

$\mathrm{R}$ = waktu koagulasi (menit)

\section{Hasil dan Pembahasan}

\section{Pengaruh lama inkubasi}

Berdasarkan hasil penelitian pengaruh lama inkubasi terhadap rendemen enzim rennet Mucor pusillus dapat diketahui rendemen enzim rennet Mucor pusillus tertinggi pada waktu inkubasi 7 hari yaitu 3,59 RU/g. Pada hari ke-10 justru menunjukkan adanya penurunan hasil rendemen (Gambar 1). Terjadinya perubahan ini disebabkan dalam sintesis enzim ekstraselluler dikenal dengan adanya istilah represi dan induksi enzim. Induksi enzim adalah usaha memperbaiki mekanisme pembentukan produk dengan melakukan kontrol lingkungan, sedangkan represi adalah fenomena yang menyebabkan pengurangan atau penghambatan kecepatan sintesis enzim dalam metabolisme.

Dari hasil analisis di atas dapat diketahui bahwa sintesis rennet oleh Mucor pusillus direpresi pada tahap awal pertumbuhan mikrobia. Menurut Wiersma (1978), sintesis enzim ekstraselluler direpresi pada tahap awal pertumbuhan, tahap pertumbuhan eksponensial dan tahap pertumbuhan tetap. Hal ini berarti sintesis enzim ekstraselluler terjadi pada tahap akhir pertumbuhan mikrobia atau tahap pertumbuhan lambat. Pada tahap pertumbuhan ini substrat yang digunakan untuk pertumbuhan sudah habis dan jumlah repressor metabolisme dan pembentukan enzim menurun, dengan istilah lain represi dan induksi enzim tergantung pada status metabolisme dari sel. Pada fase pertumbuhan cepat, sintesis enzim akan direpresi dan pada fase pertumbuhan lambat akan terjadi derepresi sintesis enzim.

\section{Pengaruh penambahan pepton terhadap aktivitas rennet}

Pepton merupakan salah satu jenis protein dari skim susu. Komponen terbesar dari pepton adalah phosphoglikoprotein, dengan berat molekul rendah sampai sedang. Asam aminonya terdiri dari sebagian besar asam glutamat dan asam aspartat serta sebagian kecil methionin. Jumlah enzim yang diproduksi oleh mikrobia tergantung pada media dan kondisi pertumbuhan.

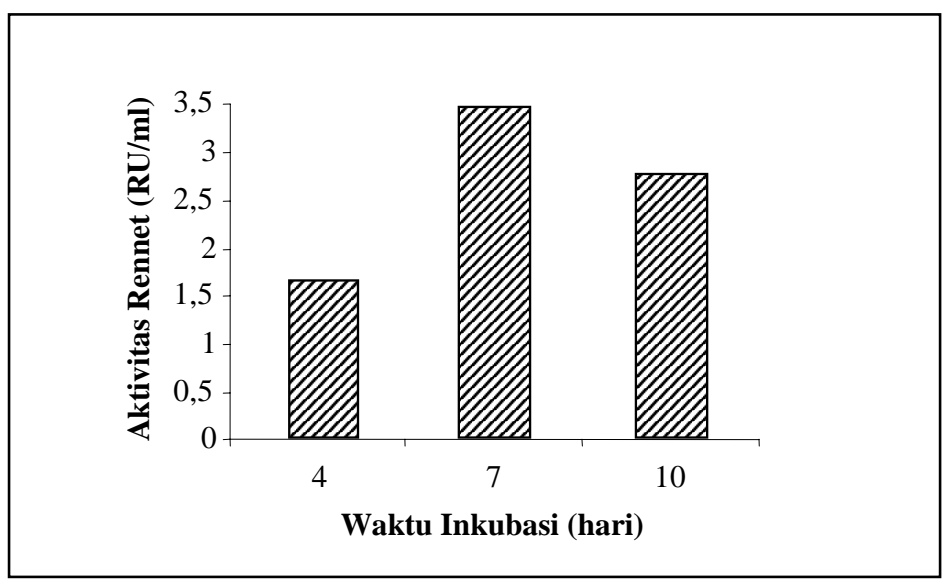

Gambar 1. Pengaruh waktu inkubasi terhadap produksi rennet Mucor pusillus. 
Pengaruh penambahan pepton terhadap aktivitas rennet Mucor pusillus dapat dilihat bahwa produksi yang tertinggi diperoleh pada penambahan pepton 1\% (Gambar 2). Apabila lebih dari 1 persen menyebabkan penurunan rendemen rennet karena kebanyakan nutrisi, sehingga pertumbuhan mikrobia terlalu cepat dan menyebabkan efek represi dari sintesis rennet. Menurut Ward (1983), ada efek represi oleh asam amino terhadap sintesis enzim ekstraseluler. Priest, (1977) Penghambatan ini terjadi pada membran sel pada taraf transkripsi, sehingga sintesis mRNA akan terhambat. Konsentrasi mRNA yang tinggi di dalam sel berkaitan langsung dengan sintesis enzim ekstraseluler. Asam amino yang berfungsi sebagai represor akan menurunkan jumlah mRNA, dan selanjutnya akan menyebabkan penurunan jumlah enzim ekstraseluler.

Asam amino glutamat dan aspartat termasuk asam amino yang menstimulir pertumbuhan M. Pusillus. Menurut Babel dan Somkuti (1968), dalam medium yang tersedia asam glutamat dan asam aspartat melebihi kebutuhan akan mempercepat pertumbuhan Mucor pusillus. Pertumbuhan yang cepat tersebut menunjukkan adanya represi katabolit pada sintesis enzim ekstraseluler (Wiersma, 1978).

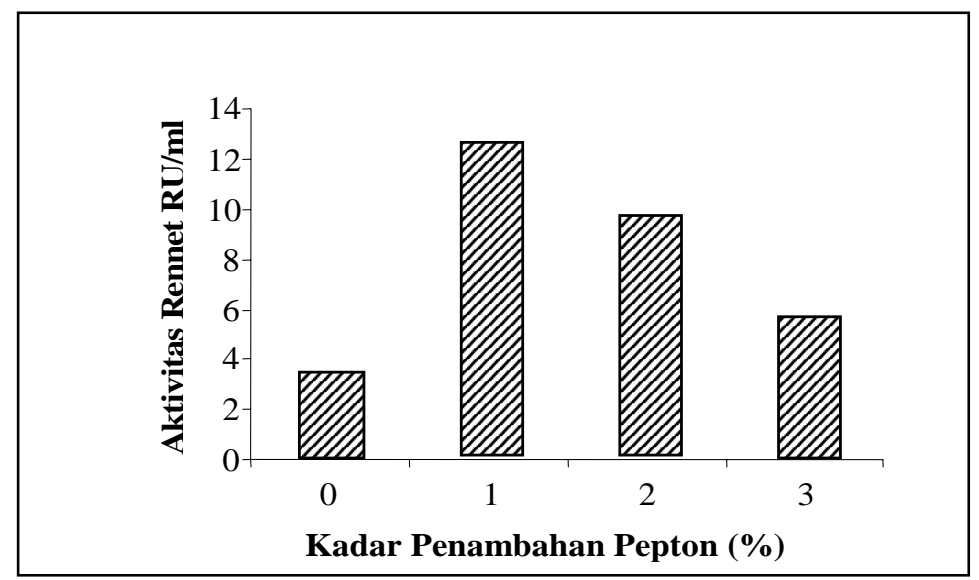

Gambar 2. Pengaruh penambahan pepton terhadap produksi rennet Mucor pusillus.

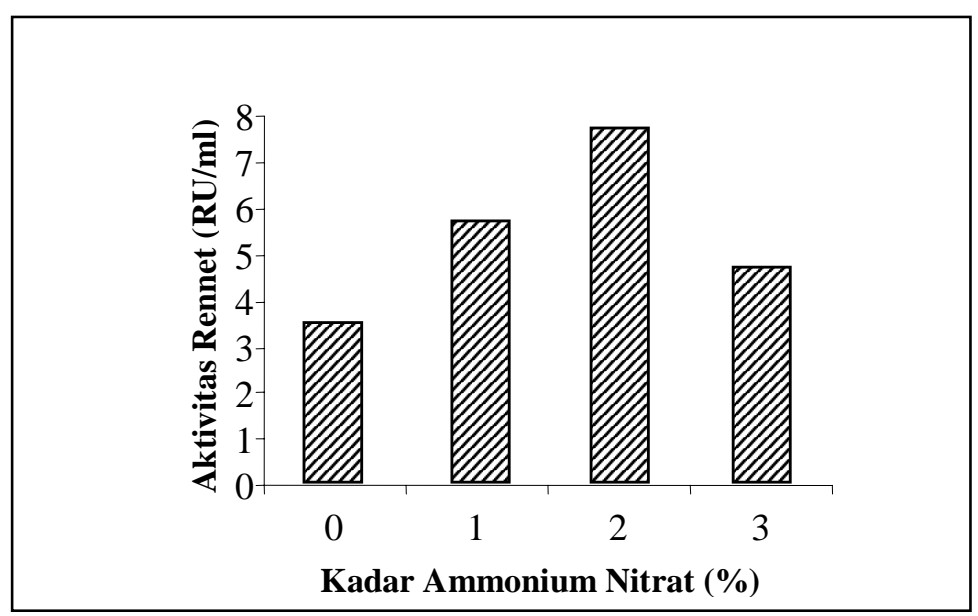

Gambar 3. Pengaruh penambahan ammonium nitrat terhadap rendemen enzim (RU/g onggok). 


\section{Pengaruh penambahan ammonium nitrat terhadap aktivitas rennet}

Sumber nitrogen bagi mikrobia didapatkan dari senyawa-senyawa nitrogen anorganik, seperti nitrat dan garam ammonium, dan nitrogen organik, seperti asam amino atau nitrogen komplek lainnya. Unsur tersebut digunakan untuk pembentukan protoplasma, dinding sel dan beberapa produk metabolisme.

Pengaruh penambahan ammonium nitrat terhadap aktivitas rennet dapat dilihat pada Gambar 3. Aktivitas tertinggi terjadi pada penambahan ammonium nitrat $2 \%$, bila lebih dari 2\% menyebabkan penurunan aktivitas rennet. Menurut Wiersma (1978) sintesis enzim protease pada berbagai jenis mikrobia direpresi oleh ion ammonium, dianggap sebagai represi oleh produk akhir.

\section{Pengaruh pH terhadap aktivitas rennet}

Hasil penelitian menunjukkan bahwa perubahan $\mathrm{pH}$ akan mempengaruhi waktu koagulasi ekstrak rennet Mucor pusillus. Semakin tinggi $\mathrm{pH}$ susu, waktu koagulasi susu semakin lama. Jadi dengan meningkatnya $\mathrm{pH}$ susu, aktivitas koagulasinya menurun. Pada $\mathrm{pH}$ 7 waktu koagulasi terlalu lama, bahkan hampir tidak akan terjadi koagulasi.

Berdasarkan Gambar 4 dapat dilihat bahwa pada $\mathrm{pH}$ 5,5 terbaik, pada pH6 - 7 perubahan $\mathrm{pH}$ lebih mempengaruhi aktivitas koagulasi Rennet, tetapi pada $\mathrm{pH}$ yang lebih tinggi perubahan $\mathrm{pH}$ lebih mempengaruhi aktivitas koagulasi ekstrak rennet Mucor pusillus. Selain itu dapat diketahui pula bahwa kedua enzim ini aktif pada kondisi asam, dan tidak aktif pada kondisi basa. Hal ini sesuai dengan Winarno (1985) yang menyatakan bahwa protease dari kapang hanya aktif pada kondisi asam. Perubahan $\mathrm{pH}$ susu menyebabkan perubahan konsentrasi ion kalsium pada fase koloid dari susu. Penurunan $\mathrm{pH}$ susu akan menyebabkan pergerakan ion kalsium dari fase koloid ke fase suspensi, sehingga kestabilan kasein susu menjadi terganggu dan mudah untuk digumpalkan.

Penurunan $\mathrm{pH}$ di bawah batas optimum akan dapat menyebabkan enzim menjadi inaktif (Richardson, 1976). Rennet dari Mucor pusillus stabil pada kisaran $\mathrm{pH}$ 4,0 - 6,0 dan paling stabil pada pH 5,5. Sardinas (1972), mengatakan bahwa rennet Mucor miehei stabil pada kisaran $\mathrm{pH}$ 2,0 - 6,0.

\section{Pengaruh suhu susu terhadap aktivitas rennet}

Kecepatan reaksi yang dikatalisis oleh enzim akan dipengaruhi dengan meningkatnya suhu. Pengaruh suhu susu terhadap waktu koagulasi dari ekstrak rennet Mucor pusillus dapat dilihat pada Gambar 5.

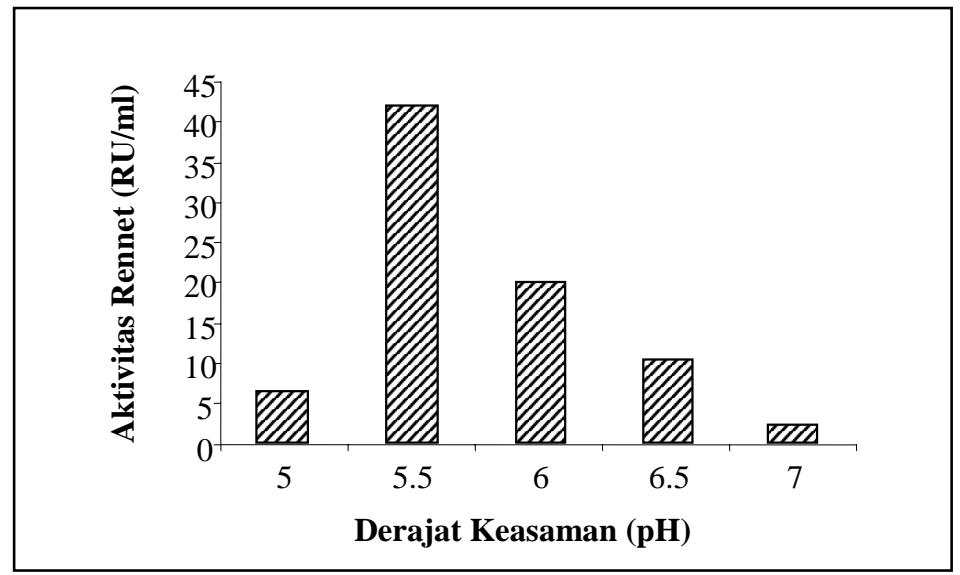

Gambar 4. Pengaruh derajat keasaman terhadap aktivitas rennet Mucor pusillus. 


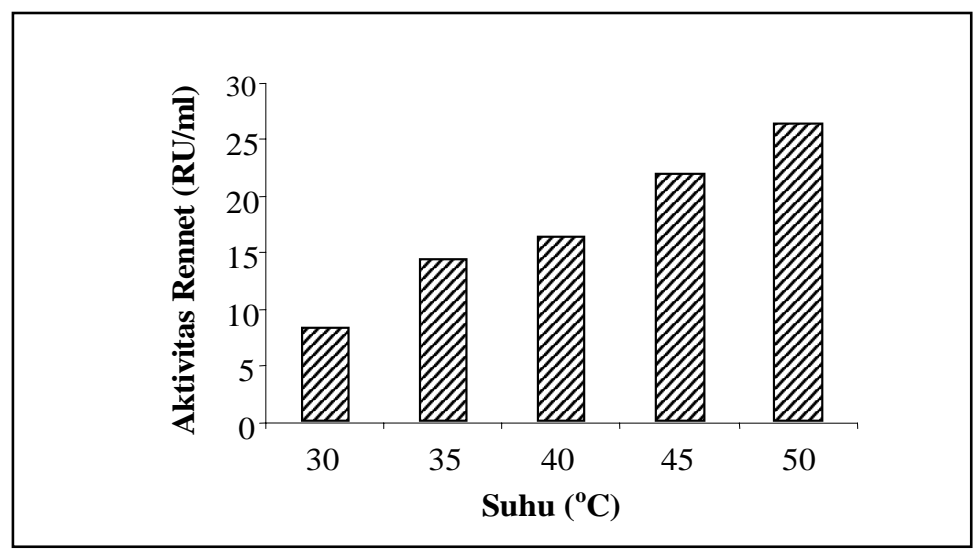

Gambar 5. Pengaruh suhu terhadap aktivitas rennet Mucor pusillus.

Peningkatan suhu susu akan mempercepat waktu koagulasi. Menurut Sardinas, (1972) rennet paling sensitif terhadap perubahan suhu susu dan bersifat termostabil. Koagulasi susu oleh rennet tidak akan terjadi pada suhu di bawah $15^{\circ} \mathrm{C}$, tetapi reaksi enzim tetap berlangsung. Penambahan rennet pada suhu di atas $60^{\circ} \mathrm{C}$ akan cepat terjadi penggumpalan dan terjadi inaktivasi enzim. Menurut Reed (1975) inaktivasi enzim mulai terjadi pada suhu $45^{\circ} \mathrm{C}$. Hal ini karena terjadinya peningkatan kecepatan pemecahan kompleks enzim substrat dan pergerakan ion kalsium dari fase koloid ke fase suspensi yang dipengaruhi oleh panas yang mengakibatkan kasein susu tidak stabil, dan sudah mengalami koagulasi. Pada praktek, tidak digunakan suhu tinggi untuk penggumpalan, karena rennet akan cepat menjadi inaktif. Padahal aktivitas rennet masih digunakan pada waktu pemeraman keju

\section{Kesimpulan}

Dari hasil penelitian dapat disimpulkan bahwa produksi enzim rennet Mucor pusillus dalam medium limbah padat tapioka (onggok) optimum pada masa inkubasi 7 hari dengan penambahan pepton $1 \%$ atau dengan penambahan ammonmium nitrat $2 \%$. Sedangkan aktivitas "crude" enzim rennet yang diperoleh dari Mucor pusillus optimum pada $\mathrm{pH}$ 5,5 dan aktivitas rennet tersebut sampai suhu $50^{\circ} \mathrm{C}$ masih menunjukkan adanya kenaikan tetapi enzim menjadi inaktif, padahal aktivitas enzim pada masa refeening masih dibutuhkan.

\section{Daftar Pustaka}

Arima, K. 1976. Mucor rennin. In International Post Graduate University Course in Microbiology. Japanese National Comition for UNISCO, Jepang.

Babel, F.J. and Somkuti. 1968. Acid Protease Synthesis by Mucor pusillus in Chemically Defained Media. J. of Bacteriology 95: 1415-1418.

Cheesman, G.C. 1981. Rennet and Cheese Making. In: Briek, G.G., Blakebrough, N. and Parker, K.J. (Eds.). p:195 Enzymes and Food Processing Appl. Sci. Publ. Ltd. London.

Khusniati, T. 2001. Identification of Spoilage Bacteria Isolated from Skim Milks by Using 20 NE. (In Indonesian). Paper in Joint Conggress of Indonesian Microbiology. Yogyakarta.

Khusniati, T., Deeth, H.C. and Wallace, R.B. 1997. Spoilage Bacteria in Commercial Skim and Whole Milks. Food Microbiology Conference. Sydney.

Khusniati, T., Intan, T. dan Rini, H. 2006. Aktivitas Protease dan Kinetika Enzimatik Rennet dari berbagai Mucor spp. J. Ilmiah Pertanian Gakuryoku XII (1): 65-68.

Priet, F.G. 1977. Extracelluar Enzyme Synthesis in Genus Bacillus, Bacteriological Rev. 41(3):711-753

Reed, G. and Pepler. 1975. Teast Technology. The AVI Publ. Co. Inc. Weastport, Connecticut.

Richardson, G.H. 1976. Dairy Industri. In: Reed, G. (Eds.). Enzym in Food Processing. p:361. $2^{\text {nd }}$. Aca. Press. New York.

Sardinas, J.L. 1972. Microbial rennet. Advance in Appll. Microbiol. 15: 39-67. 
Sastraatmadja, D.D., Hardiningsih, R. dan Yulinery, T. 2002. Karakterisasi Enzim Rennet Mucor pusillus pada Media Dedak Padi dan Singkong. Proseding Sem. Nas. Biologi XVI dan Kongres XII Perhimpunan Biologi Indonesia. 26-27 juli 2000 Bandung

Stenberg, M. 1976. Microbial rennet. J. Appl. Microbiology. 20: 136-147.

Ward, O.P. 1983. Proteinase. In: Fogrty, W.M. (Eds.). Microbial and Enzyme Biotecnology. Appl. Sci. Publ., New York.

Wiersma, M. 1978. Regulation of extracelluler Proteolitic Enzyme Synthesis in Vibrio SAI. Meppel Kupps Repro B.V., Germany. Groningen

Winarno, F.G. 1985. Enzim Pangan. PT. Gramedia Jakarta. 